\title{
Reduction of Pain and Bacterial Presence by using Double and Triple Antibiotic Pastes in Symptomatic Apical Periodontitis
}

\author{
Abdul Qadir Khan Dall, Farah Tasleem, Muhammad Farhan Khan, Kashif Ali Channar, \\ Sarwat Batool, Muhammad Ahmed Bari
}

\begin{abstract}
OBJECTIVE: To compare the efficacy of calcium hydroxide, triple antibiotic paste and double antibiotic paste in reducing bacterial load and post treatment pain in symptomatic apical periodontitis.

METHODOLOGY: In this comparative cross sectional study, 30 patients were divided into three groups. After sample collection Group A (control group) was medicated with calcium hydroxide (CH) paste, Group B with triple antibiotic paste (TAP) and Group C with double antibiotic paste (DAP). On day seven, pain status was checked by using visual analogue scale and canals were washed and another bacterial sample was taken and sent to laboratory to evaluate bacterial count. Evaluation of bacterial count and pain was done. Data analysis was performed in statistical packages for social sciences (SPSS) version 20.0. Mean \& SD was calculated. Paired T-test was applied to compare qualitative data of control group with other two groups and $P$ value $(<0.05)$ perceived as significant.

RESULTS: All baseline samples were positive for bacteria with considerable pain. Following 07 days post-treatment VAS (visual analogue scale) showed mean value of $2.5 \pm 1.269$ for $\mathrm{CH}, 1.7 \pm 0.823$ for TAP and 2.0 \pm 1.054 for DAP. In post-treatment presence of Bacteria, mean was 1.1 \pm 0.316 for $\mathrm{CH}, 1.3 \pm 0.483$ for TAP and 1.2 \pm 0.422 hence post treatment bacteria presence was lower in TAP and DAP and was higher in $\mathrm{CH}$ group.

CONCLUSION: From the results it is concluded that DAP provided better antimicrobial effect with significant decrease in pain and bacterial count in comparison to control group and almost equal in efficacy to TAP.
\end{abstract}

KEYWORDS: Triple Antibiotic Paste, Double Antibiotic Paste, Symptomatic apical periodontitis, Intracanal Medication.

This article may be cited as: Dall AQK, Tasleem F, Khan MF, Channar KA, Batool S, Bari MA. Reduction of Pain and Bacterial Presence by using Double and Triple Antibiotic Pastes in Symptomatic Apical Periodontitis. J Liaquat Uni Med Health Sci. 2019;18(02): 129-35. doi: 10.22442/jlumhs.191820615

\section{INTRODUCTION}

Symptomatic apical periodontitis (SAP) is a sequel of pulpal inflammation, which extends to peri-radicular tissues and causes moderate to severe discomfort and pain on biting and at times histologically there may be a small area of liquefaction necrosis ${ }^{1}$. Therefore; removal of these pathogenic bacteria from infected lesion is of great importance because they may sustain after endodontic therapy in root canal irregularities ${ }^{2}$. As anatomy of root canal system is very complicated and it is difficult to remove all pathogens from root canal system, various methods have been used for reducing the pathogens from root canal system like different instrumentation techniques, irrigation systems and various intracanal medicaments. Literature suggests that mechanical instrumentation or chemical irrigation alone is not sufficient to eliminate the bacteria from root canal system $^{2,3}$. Failure to properly disinfect the root canal system is the most common cited cause of pain ${ }^{4}$. Thus antimicrobial agents are also employed to maximize the elimination of pathogenic bacteria from root canal system. Several intra-canal medicaments are being used to reduce microorganisms in the canal system, making canal contents static and preventing postoperative pain ${ }^{5,6}$. Calcium hydroxide $(\mathrm{CH})$ is most commonly used intracanal medicament during root canal therapy (RCT) and is a gold standard. However; studies have shown unpredictable results to remove bacteria by using $\mathrm{CH}$ as an intracanal medication ${ }^{2,5}$.

Therefore; use of different combination of antibacterial medicaments into the root canals such as triple and/or double antibiotic pastes for disinfecting the root canal system were employed ${ }^{5-7}$. Triple antibiotic pastes (TAP), a combination of minocycline, ciprofloxacin and metronidazole has been widely used as an intracanal medicament ${ }^{7}$. Literature supports that triple antibiotic paste has a great significance in decreasing the 
intracanal bacteria and thereby relieving the symptoms. Endodontic literature confirms that the combination of antibiotic paste is very effective to evadicate bacteria from infected root canal system $^{8}$. However, presence of minocycline in TAP formula causes crown discoloration which is a drawback associated with its use. Double antibiotic paste (DAP - combination of metronidazole and ciprofloxacin only) was found to have relative better antimicrobial effects ${ }^{7,9,10}$. Double antibiotic paste contains metronidazole with ciprofloxacin and is considered to be effective drug for removal of pathogenic bacteria from root canal ${ }^{7}$. The DAP is now being used in endodontics for eradicating the problem of discoloration of tooth caused by minocycline present in TAP formulation ${ }^{11,12}$.

The aim of this clinical study is to evaluate antimicrobial effects of $\mathrm{CH}$, TAP and DAP during treatment of symptomatic apical periodontitis. Since insufficient clinical evidence is available regarding effectiveness of DAP in symptomatic apical periodontitis therefore; it is worth to find out its effectiveness in pain reduction along with bacterial count reduction for better treatment outcomes.

It was assumed that triple $\&$ double antibiotic pastes reduces more pain and bacterial load than $\mathrm{CH}$ paste as intracanal medication in symptomatic apical periodontitis. A very limited research is available on the efficacy of double antibiotic as compare to calcium hydroxide and triple antibiotic paste in local population.

\section{METHODOLOGY}

This cross sectional comparative study was conducted at Department of Operative Dentistry \& Department of Pathology, Liaquat University of Medical and Health Sciences, Jamshoro; from October 2016 to March 2017. In this study thirty patients were divided into three groups, only a single tooth of each patient was selected. Sample size was calculated by Open Epi sample size calculator in which two side significant levels (1-alpha) is 95 , power is 80 and risk or prevalence ratio is 6 . Total sample size was 30 , divided into three groups: Group A: 10 teeth of $\mathrm{CH}$ paste (Control Group), Group B: 10 teeth of triple antibiotic paste, and Group C: 10 teeth of double antibiotic paste. In this study purposive convenient sampling technique was used. The diagnostic criterion was based on history, clinical examinations and radiographic confirmation. We included patients with history of severe pain on biting and on percussion on clinical examination with small radiographic periapical lesions (<2mm radio-graphically). Patients were included above the age 16 years of either gender. While teeth which were not suitable for conventional RCT or already root treated teeth and patient with known history of allergy to antibiotics were excluded. A written informed consent was taken from every patient. Patients' personal details including age, sex and hospital registration number were recorded on a proforma. All the clinical steps were performed by postgraduate trainee. After administration of local anesthesia (Lidocaine 2\% with epinephrine 1:100000), isolation was done with rubber dam. Access preparation was done with high speed sterile diamond round bur (Mani \#4) under manual irrigation with sterile saline. Teeth were instrumented by hand $\mathrm{K}$ files with watch winding movement. The working length was approximated $1 \mathrm{~mm}$ short of the apical foramen with tactile and radiographic method. Chemo mechanical preparation was completed in the same appointment. Cleaning and shaping of canal was done by using step back technique. Irrigation was done with $2.5 \%$ sodium hypochlorite (Endo Wash, star international). A 27-gauge needle was used to distribute equal amount of Sodium Hypochlorite after each instrument. The smear layer was detached by rinsing the canal with $3 \mathrm{ml}$ of $17 \%$ EDTA (ultra-dent) concentrated solution and by leaving the canal completely filled with the solution for 1 minute, after that canal was flushed with $2 \mathrm{ml}$ of sterile solution. Finally the canal was dried with sterile paper points (Gapadent). A sterile paper point (size 20, Gapadent) was inserted full length of the canal and held on the same position for a minute to absorb any microbe for microbiological sample S1 (sample 1). Paper points were saved in an air tight container, containing Brain-Heart Infusion Broth (BHIB) and were immediately sent to the microbiological laboratory for microbiological culture. Teeth were later subjected to place intracanal medicaments to the assigned groups. For group 'A' (control group) $\mathrm{CH}$ paste (DENSPLY) was placed in the canal by the help of lentulospiral and cotton pallet was placed in the chamber. A radiograph was taken to confirm appropriate placement of $\mathrm{CH}$ paste in the canal. Temporary filling Cavit-G (3M ESPE, USA) was placed in access cavity. In group 'B' Triple antibiotic paste was placed in the canals similarly and cotton pallet was placed in the chamber. A radiograph was taken to confirm appropriate placement of TAP in the canal. Temporary filling Cavit-G (3M ESPE, USA) was placed in access cavity. For Group 'C' Double antibiotic paste was placed in the canals similarly and cotton pallet was placed in the chamber. A radiograph was taken to confirm appropriate placement of DAP in the canal. 
Temporary filling Cavit-G (3M ESPE, USA) was placed in access cavity.

On second visit which was scheduled on $7^{\text {th }}$ day, patients were evaluated for postoperative pain on VAS and recorded on proforma, after that temporary filling material Cavit-G (3M ESPE, USA) was removed from the canal and the subsequent antibiotic paste was flushed out from the canal by using irrigant and master apical file. Microbiological sample (S2) was taken with the same procedure as described for S1. Root canals were obturated with guttapercha (Gapadent) and sealer (sealapex sybranendo) with lateral compaction technique and restored. For bactrial analysis the paper points were placed in the decontaminated container with enhancement medium i.e. Brain-Heart Infusion Broth (BHIB), which is vortexed for 60 seconds to eliminate all bacteria. Brain -Heart Infusion Broth contains beef heart infusion solids $5 \mathrm{gm} / \mathrm{liter}$, proteose peptone $10.0 \mathrm{~g} / \mathrm{liter}$, sodium chloride $5 \mathrm{gm} / \mathrm{liter}$ and glucose $2 \mathrm{gm} / \mathrm{liter}$. One $\mathrm{ml}$ of $\mathrm{BHIB}$ is diluted with $9 \mathrm{ml} \mathrm{NaCl}$. This solution is autoclaved at $121^{\circ} \mathrm{C}$ at $15 \mathrm{psi}$ pressure after that it was frozen at $50^{\circ} \mathrm{C}$, poured in test tubes and stored in fridge at $2^{\circ} \mathrm{C}$. Sterility was checked by incubation at $37^{\circ} \mathrm{C}$ for 24 to 48 hours. Quality Control (QC), checked by using American Type Culture Collection (ATCC) strain of bacillus. One $\mathrm{ml}$ of sample was inoculated in petri dish containing blood agar at $37^{\circ} \mathrm{C}$ for 24 hours in gas vacuum. After 24 hours colonies of bacteria were counted visually.

Effectiveness of antibiotic paste was evaluated with the existence or non-existence of bacteria: Positive Effect $=$ no bacteria exist, Negative Effect $=$ bacteria exist.

Bacterial analysis was performed by counting the number of colonies of bacteria in the specimen: No growth $=$ no colonies seen, Few growths = less than 10 colonies of bacteria seen, Moderate growth = less than 100 colonies more than 10 colonies of bacteria seen, Heavy growth $=$ more than 100 colonies of bacteria seen.

All the clinical steps were performed by a single operator and all the samples were sent to same laboratory. Data analysis was performed on statistical packages for social sciences (SPSS) version 20.0. Mean \& SD was calculated for variables like age, pain. Frequency and percentage was calculated for qualitative variables like gender, type of tooth, bacterial growth. Paired T-test was applied to compare qualitative data of control group with other two groups to find the $P$ value $(<0.05)$ as significant.

\section{RESULTS}

Total 30 patients with only single tooth were included in the study. Mean age was found out to be $29.83 \pm 9.403$. This descriptive information regarding age and frequency (\%) of involved teeth presented in Table I and Figure II. Among the patients who came for the treatment $46.67 \%$ were males and 53.33 were female patients. Gender distribution shown in Figure I. Out of total 30 teeth $(n=30)$ the highest frequency was seen in lower $1^{\text {st }}$ molar $43.3 \%(n=13)$, followed by lower 1st premolars, upper incisors and upper $1^{\text {st }}$ molars with $13.3 \%(n=4)$ each, lower canine, upper $1^{\text {st }}$ premolar with $6.7 \%(n=2)$ each and lower incisor with $3.3 \%(n=1)$ shown in Figure II. Furthermore, the subjects were divided into three groups of 10 subjects with single tooth.

The pre and post-treatment pain shown in Table II in which all patients came with severe pain but after 7 days there was significant reduction of pain in Group $B$ and $C$ patients while in Group A patients pain was relatively higher.

The results shown in Table III and IV, before treatment all the patients came with severe pain. After 7 days post-treatment pain and the calculation of Mean were found out to be 2.5 for $\mathrm{CH}, 1.7$ for TAP and 2.0 for DAP. The results for Standard deviation are $\mathrm{CH}$ (1.269), TAP (0.823) and DAP (1.054) respectively. These results confirm that the results obtained are validating the hypothesis that the TAP \& DAP are better options for reducing pain.

The pre \& post-treatment presence of bacteria, the calculation of Mean $1.1 \pm 0.316$ for $\mathrm{CH}, 1.3 \pm 0.483$ for TAP and $1.2 \pm 0.422$ for DAP, showing the bacterial presence was most negative in TAP and than in DAP and the most positive presence in $\mathrm{CH}$ Table $\mathbf{V}$. The Pair T-Test statistics revealed that the paired difference of presence of bacteria before and after treatment were statistically significant for TAP and DAP as their $P$-value is less than 0.05 i.e. $(p \leq 0.05)$ whereas for the $\mathrm{CH}$ the $p$-value is greater than 0.05 ( $p$ $>0.05$ ) and it suggest that the result is not statistically significant and this condition is validating the hypothesis. The post-treatment severity of bacterial Growth, the calculation of Mean is found out to be 2.6 for $\mathrm{CH}, 1.2$ for TAP and 1.6 for DAP and the Standard Deviation are $\mathrm{CH}$ (0.843), TAP (1.033) and DAP (1.075) validating the Hypothesis that the TAP and DAP is better than $\mathrm{CH}$ in terms of bacterial growth. The Pair T-Test statistics revealed that the paired difference of severity of bacterial growth before and after treatment were statistically significant for TAP and DAP as their P-value is less than 0.05 i.e. ( $p \leq$ $0.05)$ whereas for the $\mathrm{CH}$ the $\mathrm{p}$-value is greater than $0.05(p>0.05)$ and it suggest that the result is not statistically significant Table VI. 
Reduction of Pain and Bacterial Presence

FIGURE I: GENDER DISTRIBUTION OF SUBJECTS

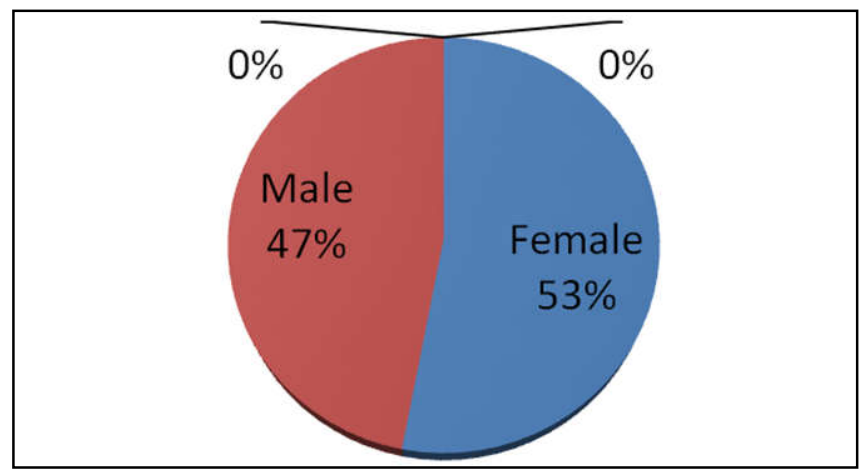

TABLE I: DESCRIPTIVE STATISTICS FOR AGE OF SUBJECTS

\begin{tabular}{|l|c|}
\hline \multicolumn{2}{|c|}{ Patients' Age } \\
\hline No of Patients & 30 \\
\hline Min. & 16 \\
\hline Max. & 45 \\
\hline Mean & 29.83 \\
\hline Std. Deviation & 9.403 \\
\hline
\end{tabular}

FIGURE II: TYPE OF TOOTH INVOLVED

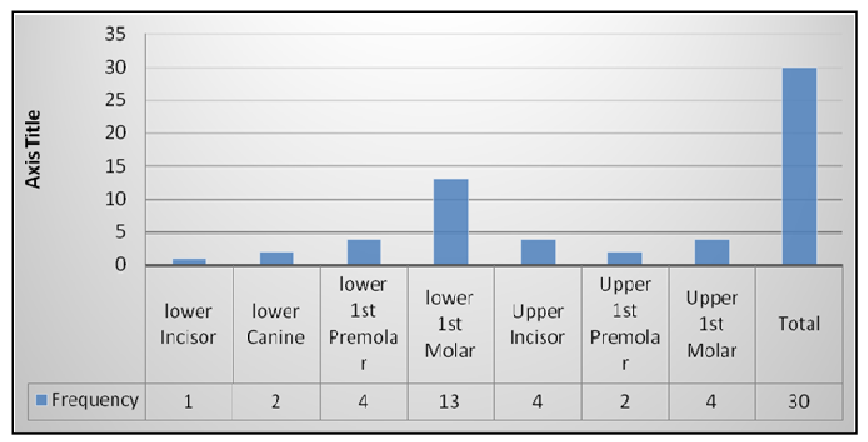

TABLE IV: MEAN AND STANDARD DEVIATION ACHIEVED FROM PAIRED SAMPLE STATISTICS OF PAIN SCALE

\begin{tabular}{|l|c|c|c|c|}
\hline \multirow{2}{*}{ Group } & \multicolumn{4}{|c|}{ Pain Scale } \\
\cline { 2 - 5 } & \multicolumn{2}{|c|}{ Before } & \multicolumn{2}{c|}{ After } \\
\cline { 2 - 5 } & Mean & $\begin{array}{c}\text { Std. } \\
\text { Deviation }\end{array}$ & Mean & $\begin{array}{c}\text { Std. } \\
\text { Deviation }\end{array}$ \\
\hline CH & 4 & 0 & 2.5 & 1.269 \\
\hline TAP & 4 & 0 & 1.7 & 0.823 \\
\hline DAP & 4 & 0 & 2.0 & 1.054 \\
\hline
\end{tabular}

TABLE II: PAIN SCALE BEFORE AND AFTER APPLICATION OF INTRACANAL MEDICAMENTS

\begin{tabular}{|l|c|c|c|c|c|c|c|c|c|}
\hline \multirow{2}{*}{ Group } & \multirow{2}{*}{$\mathbf{N}$} & \multicolumn{9}{|c|}{ Before } & \multicolumn{4}{c|}{ After } \\
\cline { 3 - 11 } & & No Pain & Mild Pain & $\begin{array}{c}\text { Moderate } \\
\text { Pain }\end{array}$ & $\begin{array}{c}\text { Severe } \\
\text { Pain }\end{array}$ & No Pain & Mild Pain & $\begin{array}{c}\text { Moderate } \\
\text { Pain }\end{array}$ & $\begin{array}{c}\text { Severe } \\
\text { Pain }\end{array}$ \\
\cline { 3 - 11 } & & 0 & 0 & 0 & 10 & 3 & 2 & 2 & 3 \\
\hline $\mathrm{CH}$ & 10 & 0 & 0 & 0 & 10 & 4 & 3 & 2 & 1 \\
\hline TAP & 10 & 0 & 0 & 0 & 10 & 2 & 3 & 3 & 2 \\
\hline DAP & 10 & 0 &
\end{tabular}

TABLE III: PRESENCE OF BACTERIA AMONG THE PATIENTS AND SEVERITY OF BACTERIAL GROWTH (NUMBER OF COLONIES) AMONG THE PATIENTS

\begin{tabular}{|c|c|c|c|c|c|c|c|c|c|c|c|c|c|}
\hline \multirow{3}{*}{ Group } & \multirow{3}{*}{$\mathbf{N}$} & \multicolumn{4}{|c|}{ Presence of bacteria } & \multicolumn{8}{|c|}{ Severity of bacterial growth } \\
\hline & & \multicolumn{2}{|c|}{ Before } & \multicolumn{2}{|c|}{ After } & \multicolumn{4}{|c|}{ Before } & \multicolumn{4}{|c|}{ After } \\
\hline & & Positive & Negative & Positive & Negative & $\begin{array}{c}\text { No } \\
\text { growth }\end{array}$ & $\begin{array}{c}\text { Few } \\
\text { growth }\end{array}$ & $\begin{array}{c}\text { Moderate } \\
\text { growth }\end{array}$ & $\begin{array}{l}\text { Heavy } \\
\text { growth }\end{array}$ & $\begin{array}{c}\text { No } \\
\text { growth }\end{array}$ & $\begin{array}{c}\text { Few } \\
\text { growth }\end{array}$ & $\begin{array}{l}\text { Moderate } \\
\text { growth }\end{array}$ & $\begin{array}{l}\text { Heavy } \\
\text { growth }\end{array}$ \\
\hline $\mathrm{CH}$ & 10 & 10 & $\mathrm{CH}$ & 9 & 1 & 0 & 0 & 0 & 10 & 1 & 1 & 3 & 5 \\
\hline TAP & 10 & 10 & TAP & 7 & 3 & 0 & 0 & 0 & 10 & 3 & 3 & 3 & 1 \\
\hline DAP & 10 & 10 & DAP & 8 & 2 & 0 & 0 & 0 & 10 & 2 & 2 & 4 & 2 \\
\hline
\end{tabular}

TABLE V: MEAN AND STANDARD DEVIATION ACHIEVED FROM PAIRED SAMPLE STATISTICS OF PRESENCE OF BACTERIA $(n=30)$

\begin{tabular}{|l|c|c|c|c|}
\hline \multirow{2}{*}{ Group } & \multicolumn{4}{|c|}{ Presence of Bacteria } \\
\cline { 2 - 5 } & \multicolumn{2}{|c|}{ Before } & \multicolumn{3}{c|}{ After } \\
\cline { 2 - 5 } & Mean & Std. Deviation & 1.1 & 0.316 \\
\hline CH & 1 & 0 & 1.3 & 0.483 \\
\hline TAP & 1 & 0 & 1.2 & 0.422 \\
\hline DAP & 1 & 0 & & Std. Deviation \\
\hline
\end{tabular}


Abdul Qadir Khan Dall, Farah Tasleem, Muhammad Farhan Khan, Kashif Ali Channar, Sarwat Batool, Muhammad Ahmed Bari

TABLE VI: MEAN AND STANDARD DEVIATION ACHIEVED FROM PAIRED SAMPLE STATISTICS OF SEVERITY OF BACTERIAL GROWTH

\begin{tabular}{|l|c|c|c|c|}
\hline \multirow{2}{*}{ Group } & \multicolumn{3}{|c|}{ Severity of Bacterial Growth } \\
\cline { 2 - 5 } & \multicolumn{2}{|c|}{ Before } & \multicolumn{2}{c|}{ After } \\
\cline { 2 - 5 } & Mean & $\begin{array}{c}\text { Std. } \\
\text { Deviation }\end{array}$ & Mean & $\begin{array}{c}\text { Std. } \\
\text { Deviation }\end{array}$ \\
\hline CH & 3 & 0 & 2.6 & 0.843 \\
\hline TAP & 3 & 0 & 1.2 & 1.033 \\
\hline DAP & 3 & 0 & 1.6 & 1.075 \\
\hline
\end{tabular}

\section{DISCUSSION}

The main objective of endodontic treatment is to decrease the bacterial burden from the root canal system to disinfect root canal system. For this purpose various antimicrobial medicaments are being used in endodontics ${ }^{13} . \mathrm{CH}$ is the most commonly used inter-appointment dressing material over the years ${ }^{5,14}$. Therefore; in this study $\mathrm{CH}$ was used as control group to compare severity of pain, bacterial count and growth with TAP and DAP. In this study we found decrease pain in group $B$ and group $C$ in comparison to control group. Four patients experienced no pain and three patients have mild pain, two patients with mild pain and one patient with severe pain out of ten patients after using TAP. Two patients remained pain free and three each had mild and moderate pain and two with severe pain out of ten patients after the application of DAP. In control group, out of ten patients, severe pain was recorded in three patients, moderate and mild pain in two patients and no pain in three patients. Findings of our study are similar to the study conducted by Gyanani H 2016 ${ }^{15}$ when they used VRS and found considerable reduction in pain with TAP. Parsad LK $2016^{6}$ also used visual analogue scale like our study to record pain after using $\mathrm{CH}$ and TAP as intracanal dressing and found significant pain reduction with TAP group. Sabbagh S $2018^{11}$ also found symptom free patient when they applied DAP as intracanal medication in their case report. Contrary to our results Abouelenien SS $2018^{16}$ in their study found less post operative pain in apical periodontitis with DAP group than $\mathrm{CH}$ after only 24 hours, while we evaluated postoperative pain after 7 days.

Regarding bacterial reduction studies suggest that use of TAP as intracanal medicament is very effective in reduction of bacteria from root canal system ${ }^{7}$. TAP contains minocycline, ciprofloxacin and metronidazole which provide bactericidal effect for a wide range of bacterial species that are present in periapical lesions but it causes undesirable tooth discoloration ${ }^{10}$. DAP was used in this study as a third group (Group C) to overcome the problem of tooth discoloration caused by minocycline present in TAP. Double antibiotic paste was compared with $\mathrm{CH}$ and triple antibiotic paste for its better performance in clinical trials ${ }^{11}$. The results showed that bacteria were still present after the use of $\mathrm{CH}$. Bacterial load was reduced significantly after the use of DAP and TAP dressing placed in the root canals. In control group postoperatively there was little difference regarding bacterial count and pain was observed. These findings match with the study of Tanumihardja M $2015^{7}$ which reported increase of bacterial load in the majority of the samples with relative risk of 1.3 and were not statistically prominent $^{7}$. In one case report, same results were claimed with increase of bacterial load in almost half of the root canals $(46.67 \%)$ after application of $\mathrm{CH}$ as intracanal medicament ${ }^{17}$.

Studies confirm that TAP is more effective than $\mathrm{CH}$ and reported drawbacks of $\mathrm{CH}$ as intracanal medicament are consistent with our results ${ }^{7,18,19}$. Contrary to our results one study noticed no advantage of DAP medication over $\mathrm{CH}$, but they used canal dressings for 48 hours only ${ }^{16}$. With contrast to our findings Narang K 2018 ${ }^{20}$ found no difference between antibiotic pastes and $\mathrm{CH}$ in apical periodontitis in their case reports. Dressing with local application of TAP and DAP has been reported to be successful in the treatment of symptomatic apical periodontitis $^{7,21}$. In animal studies Fahmy $\mathrm{SH}$, et $\mathrm{al}^{21}$. showed favouable results with DAP in apical periodontitis.

In our study TAP and DAP not only decreased the bacterial load considerably in infected pulps but also prevented the growth of bacteria in root canal system. Three samples showed no growth of bacteria and three have showed few growths of bacteria and only one sample have showed heavy growth after using triple antibiotic paste and two samples showed no growth of bacteria, two have showed few growth and only two samples have showed heavy growth after using double antibiotic paste which is statistically significant. Results of our study also consistent with the findings of Adl A $2012^{18}$ who also found TAP more effective than $\mathrm{CH}$ against canal bacteria. Regarding effectiveness of DAP identical results like this study were identified by Iwaya SI $2001^{12}$ and Sabrah $\mathrm{AH}$ $2013^{10}$. but with different methodologies. An additional benefit of DAP was discovered by Sabrah AH $2015^{22}$. as DAP showed a significantly longer residual antibacterial effect compared with the same concentrations of TAP. This property of DAP increases the efficacy of medicament in the infected root canals. 


\section{CONCLUSION}

From the results it is concluded that DAP provided better antimicrobial effect with significant decrease in pain and bacterial count in comparison to control group in symptomatic apical periodontitis. DAP has promising antimicrobial effect with significant decrease in pain threshold and bacterial count and almost equal in efficacy to TAP with additional advantage of no initial sign of discoloration of the teeth which is associated with triple antibiotic paste.

Limitations: A single operator evaluated the patients and done the culture method so operator bias could not be rejected. This study also lacks power as it contains small sample size therefore for better results a large sample size is recommended for further studies.

Ethical Permission: ERC approval letter of LUMHS No. 24412/15 dated: 02-09-2016.

Conflict of Interest: There is no conflict of interest to declare.

Funding: Self funded.

\section{REFERENCES}

1. Kenneth HM, Cohen S. Cohen's pathway of pulp 10th ed. St.Louis, Missouri, Elsevier; 2011.

2. Tan KS, Yu VS, Quah SY, Bergenholtz G. Rapid method for the detection of root canal bacteria in endodontic therapy. J Endod. 2015; 41(4): 44750. doi: 10.1016/j.joen.2014.11. 025.

3. Rahimi S, Janani M, Lotfi M, Shahi S, Aghbali A, Pakdel MV, et al. A review of antibacterial agents in endodontic treatment. Iran Endod J. 2014; 9(3): 161-68.

4. Anjaneyulu K, Nivedhitha MS. Influence of calcium hydroxide on the post treatment pain in endodontics: A systematic review. J Conserv Dent. 2014; 17(3): 200-7. doi: 10.4103/09720707.131775.

5. Murvindran V, Raj JD. Antibiotics as an intracanal medicament in endodontics. J Pharm Sci Res. 2014; 6(9): 297-301.

6. Prasad LK, Tanwar BS, Kumar KN. Comparison of calcium hydroxide and triple antibiotic paste as intracanal medicament in emergency pain reduction: In vivo study. Int J Oral Care Res. 2016; 4(4): 244-246. doi: 10.5005/jp-journals-10051-0054.

7. Tanumihardja M, Wahyuni S, Pattelongi I, Samad $\mathrm{R}$, Wahid S. Antimicrobial effects of triantibiotic paste in endodontic treatment of chronic apical periodontitis. Sch J Dent Sci. 2015; 2(1): 58-62.

8. Valverde ME, Baca $P$, Ceballos L, Fuentes MV, Ruiz-Linares M, Ferrer-Luque CM. Antibacterial efficacy of several intracanal medicaments for endodontic therapy. Dent Mater J. 2017; 36(3): 319-324. doi: 10.4012/dmj.2016-102.

9. Balasubramaniam R, Jayakumar $S$. Antibiotics in endodontics - A concise review. Int J Appl Dent Sci. 2017; 3(4): 323-329.

10. Sabrah AH, Yassen GH, Gregory RL. Effectiveness of antibiotic medicaments against biofilm formation of Enterococcus faecalis and Porphyromonas gingivalis. J Endod. 2013; 39 (11):1385-9. doi: 10.1016/j.joen.2013.05.003.

11. Sabbagh S, Shirazi AS, Torabzadeh H. Double Antibiotic Paste for Management of External Inflammatory Root Resorption. Iran Endod J. 2018; 13(4): 569-572.

12. Iwaya SI, Ikawa M, Kubota M. Revascularization of an immature permanent tooth with apical periodontitis and sinus tract. Dent Traumatol 2001; 17(4): 185-7.

13. Taneja S, Kumari M, Parkash H. Nonsurgical healing of large periradicular lesions using a triple antibiotic paste: A case series. Contemp Clin Dent. 2010; 1(1):31-35. doi: 10.4103/0976-237X. 62519

14. Bystrom A, Sundqvist G. Bacteriologic evaluation of the effect of 0.5 percent sodium hypochlorite in endodontic therapy. Oral Surg Oral Med Oral Pathol. 1983; 55(3): 307-12.

15. Gyanani H, Chhabra N, Parmar GR.Comparative assessment of efficacy of two different pretreatment single oral doses of betamethasone on inter-appointment and postoperative discomfort: An in vivo clinical evaluation. J Conserv Dent. 2016; 19(6): 564-8.

16. Abouelenien SS, Ibrahim MS, Shaker OG, Ahmed GM. Evaluation of postoperative pain in infected root canals after using double antibiotic paste versus calcium hydroxide as intra-canal medication: A randomized controlled trial. F1000 Research. 2018; 7: 1768-76. doi:10.12688/f1000 research.16820.1

17. Endo MS, Ferraz CC, Zaia AA, Almeida JF, Gomes BP. Quantitative and qualitative analysis of microorganisms in root-filled teeth with persistent infection: Monitoring of the endodontic retreatment. Eur J Dent. 2013; 7(3): 302-9. doi: 10.4103/1305-7456.115414.

18. Adl A, Shojaee NS, Motamedifar M. A comparison between the antimicrobial effects of triple antibiotic paste and calcium hydroxide against Entrococcus faecalis. Iran Endod J. 2012; 7(3): 149-55.

19. Revathi N, Sharath Chandra SM. Merits and Demerits of Calcium Hydroxide as a Therapeutic Agent: A Review. Int J Dent Sci Res. 2014; 2(6B): 1-4.doi:10.12691/ijdsr-2-6B-1. 
20. Narang K, Nayak M, Wahed A, George JV, Mathew S. Management of Non-Vital Teeth with Open Apices using MTA: Two Case Reports. J Dent Oro-Facial Res 2018; 14(01): 75-9.

21. Fahmy SH, Hassanien EES, Nagy MM, El Batouty KM, Mekhemar M, Fawzy El Sayed K, et al. Investigation of the regenerative potential of necrotic mature teeth following different revascularisation protocols. Aust Endod J. 2017; 43(2): 73-82. doi: 10.1111/aej.12210.

22. Sabrah $A H$, Yassen $G H$, Spolnik KJ, Hara AT, Platt J, Gregory RL. Evaluation of Residual Antibacterial Effect of Human Radicular Dentin Treated with Triple and Double Antibiotic Pastes. J Endod. 2015; 41(7): 1081-1084. doi: 10.1016/j.joen.2015.03.001.

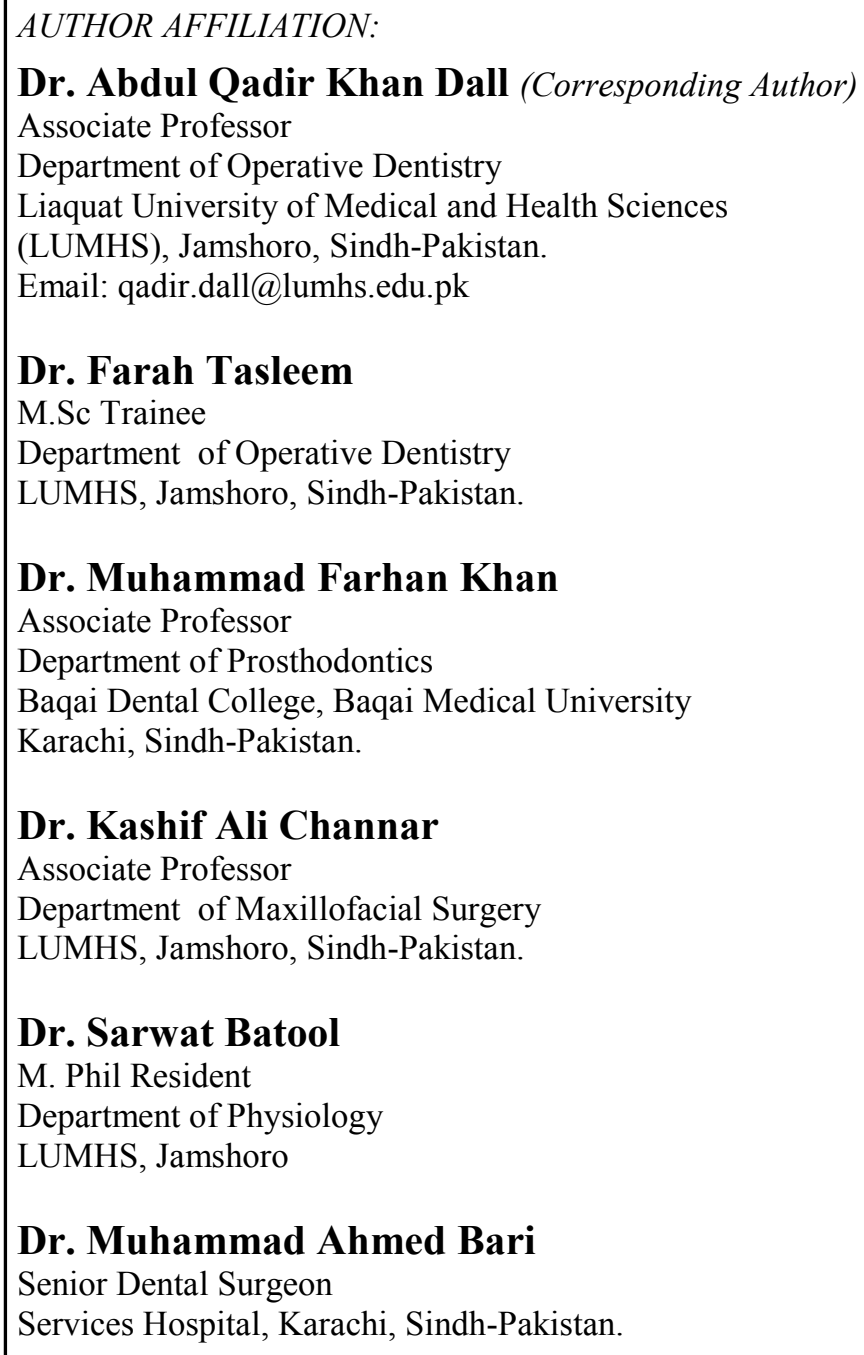

\section{Dr. Farah Tasleem}

M.Sc Trainee

Department of Operative Dentistry

LUMHS, Jamshoro, Sindh-Pakistan.

Dr. Muhammad Farhan Khan

Associate Professor

Department of Prosthodontics

Baqai Dental College, Baqai Medical University

Karachi, Sindh-Pakistan.

\section{Dr. Kashif Ali Channar}

Associate Professor

Department of Maxillofacial Surgery

LUMHS, Jamshoro, Sindh-Pakistan.

\section{Dr. Sarwat Batool}

M. Phil Resident

Department of Physiology

LUMHS, Jamshoro

\section{Dr. Muhammad Ahmed Bari}

Senior Dental Surgeon

Services Hospital, Karachi, Sindh-Pakistan. 